ARTICLE

https://doi.org/10.1057/s41599-019-0276-z

\title{
Shall not be infringed: how the NRA used religious language to transform the meaning of the Second Amendment
}

\author{
Jessica Dawson ${ }^{1}$
}

\begin{abstract}
Understanding the deep meaning of the Second Amendment is critical to understanding American gun culture. The centrality of the Second Amendment in American culture can be better understood through the intersection of American nationalism with Protestant Christianity. This paper argues that the National Rifle Association (NRA) has capitalized on the religious nationalism that arose in the late 1970s alongside the Moral Majority and has increasingly used religious language to shape the discourse surrounding the Second Amendment. Understanding the transformation of the Second Amendment from an important Constitutional amendment to an article of faith in religious nationalism provides new insight about the meaning of guns for American identity. The use of religious rhetoric, such as references to evil combined with references to civic obligation, illustrates the merging of American civic religion with the New Christian Right's rhetoric. Using issues of the American Rifleman to investigate the changing discourse since the mid-1970s, this paper demonstrates how the NRA increased its use of religious language to frame the political debate about gun rights through a religious nationalist lens.
\end{abstract}

\footnotetext{
${ }^{1}$ Department of Behavioral Sciences and Leadership, United States Military Academy at West Point, Thayer Road, West Point, NY 10928, USA. Correspondence and requests for materials should be addressed to J.D. (email: jssdawson@gmail.com)
} 


\section{Introduction: Second Amendment and religious nationalism}

erhaps no other subject in America engenders the level of controversy and intensity of emotions as the Second Amendment. Gun rights advocates and gun control advocates occupy opposing positions on the political spectrum regarding the role of guns in America. The Second Amendment has been a motivating force in American politics since at least the 1960s, when violence shook the nation and a series of public assassinations lead to a "moment of profound popular revulsion against guns" (Hofstadter, 1970, p. 9). Recent studies have begun to consider gun in the context of American religion (Mencken and Froese, 2017; O'Neill, 2007; Yamane, 2017a). With the rise of studies of religious nationalism, the investigation of gun culture at the intersection of religion and nationalism is a relatively recent development (Whitehead et al., 2018). In this paper, I explore the National Rifle Association's (NRA) use of religious language to increasingly frame the political debate about gun rights through a religious nationalist lens.

This paper contributes to the rich literature that has investigated the changing meaning of the Second Amendment over time. The Second Amendment has been broadly studied in political (Carlson, 2015; Horwitz and Anderson, 2009; Obert, 2018; Winkler, 2013), legal (Waldman, 2015; Winkler, 2013), gender (Dunseith, n.d.; Melzer, 2012; O’Neill, 2007), and historical (Burbick, 2006; Dunbar-Ortiz, 2018) contexts. DunbarOrtiz's (2018) Loaded: A Disarming History of the Second Amendment expanded on this rich literature and demonstrated how larger social and political forces created the myths surrounding the Second Amendment and the role of guns in American history. A major contribution of that work was to situate these myths in the larger patterns of the violent control of native and slave populations (Dunbar-Ortiz, 2018; Obert, 2018). This historical context is critical for any discussion of religious nationalism today, given the dominance of white Christian nationalism in the current political sphere (Gorski, 2017a). Sociological studies of gun culture and the Second Amendment are experiencing a resurgence (Burbick 2006; Yamane 2017b; Stroud 2016; Hovey et al., 2017). Recent studies have begun considering the role of guns in American religious contexts (Mencken and Froese, 2017; Yamane, 2017a). Other studies have analyzed gun-related texts for religious symbolism. Lamy (1992) analyzed Soldier of Fortune magazine to demonstrate the presence of apocalyptic millennialism (Yamane et al., 2018), laying the foundation for investigating the links between gun culture and religious beliefs. Gibson's Warrior Dreams (1994) also used Soldier of Fortune and other gun magazines to explain the rise of paramilitary culture in the post-Vietnam years. I expand on these studies to demonstrate how the NRA has increasingly used religious language to shape its argument in favor of the Second Amendment - that is, that the right to bear arms is part of God's covenant with America (Gorski, 2017b).

The NRA's role in transforming the Second Amendment to one of central political importance has been well documented (Dunbar-Ortiz, 2018; Halbrook, 2008; Melzer, 2012; Waldman, 2015). Melzer's Gun Crusaders provided an in-depth study of NRA members and how the NRA as a social movement organization mobilized members during elections with differing levels of commitment to protect gun rights through the political process (2012). Melzer's work revealed critical early links between the NRA's shaping argument around the Second Amendment and the use of religious nationalism. Members of the NRA leadership have argued that "you would get a far better understanding if you approached [the NRA] as if you were approaching one of the great religions of the world" (Gibson, 1994, p. 253; Melzer, 2012, p. 15). Whereas much research on gun culture views the Second Amendment in a political and legal context, I argue that the NRA has capitalized on the religious nationalism that arose in the late 1970s with the rise of the Moral Majority and the New Christian Right (Wuthnow, 1990) and has increasingly used religious language to shape the discourse surrounding the Second Amendment.

Before turning to the links between religious nationalism and the Second Amendment, I summarize the political, legal, and cultural context in order to discuss how the meaning around the Second Amendment has already been studied.

\section{The evolution of the Second amendment}

The transformation of the NRA from a shooting club to a gun rights advocacy organization in the 1970s is well documented (Halbrook, 2013; Hovey et al., 2017; Waldman, 2015; Winkler, 2013) and, because of space constraints, will be noted only briefly here. Rising out of both the violence and high-profile assassinations of the 1960s, Second Amendment hardliners diverged sharply from more moderate gun rights advocates, arguing for principled opposition to any gun control measure (Knox, 2009). Harlan Carter served as the first director of the NRA's lobbying arm, the Institute for Legislative Affairs (ILA), begun in 1975. He later served as the president of the NRA, shaping the NRA's political and legal efforts toward "Second Amendment absolutism" (Hodges, 2015, p. 91) -that is, the unrestricted right of individuals to keep and bear arms. Neal Knox was a subsequent director of the ILA and president of the NRA before being replaced by Charlton Heston in 1997 (Knox, 2009). Knox remained a dedicated proponent of gun rights until his death in 2005. Both Carter and Knox helped orchestrate the 1977 takeover of the board of directors in an event that would be known the Revolt in Cincinnati, when members of the new guard pushed out old guard board members who were more willing to compromise on gun rights. The NRA focused their efforts on electing congressmen who supported gun rights as an individual right protected by the legal system that they-and many Americans-view as handed down by God through the Constitution (Bonikowski and DiMaggio, 2016; Dunbar-Ortiz, 2018; Gorski, 2017b).

\section{Individual rights}

The key point of disagreement over the legal and historical framing of the Second Amendment argues about whether it is rooted in "civic republicanism and militia service [or whether]... it protected a bit more, including the right to own and acquire firearms for non-militia-related purposes, such as self-defense" (Charles, 2018, p. 302). The legal strategy advocated by hardliners such as Carter and Knox, centered on the goal of enshrining the Second Amendment as an individual right (Halbrook, 2008; Knox, 2009; Waldman, 2015). This argument was premised on the second half of the Second Amendment and sidestepped the initial text of the amendment referring to the "well-regulated militia" (Waldman, 2015). From 1980 to 1999, a "small collective of lawyers were able to usher in a flood of individualistic studies so that they outnumbered the total number of militia-centric studies by almost two to one" (Charles, 2018, p. 301). This individualized interpretation of the Second Amendment became known as the Standard Model (Winkler, 2013).

Even if the Second Amendment did not enshrine an individual right in the Constitution, "the individual right to bear arms has never depended on [the Second Amendment]. At least forty-three of the fifty state constitutions contain language that clearly and unambiguously protects the right of individuals to own guns" (Winkler, 2013, p. 33). These are not modern legal provisions. In keeping with the individual right to keep and bear arms already protected in the vast majority of states, the affirmation of this 
right at the federal level became established legal precedent in the now-famous Heller case (554 U.S. 570 [2008]) argued before the Supreme Court in 2008.

The individual rights argument is not unique to the gun rights movement. "The 14th Amendment's guarantee of equal protection under the law" (MacLean, 2018, p. 14) was a constitutional shift (Simon, 2004) that reframed how the Constitution would be applied. States' rights 'yielded in preeminence to individual rights" (MacLean, 2018, p. 14). The close of the 1960s resulted in a constitutional reformulation of the "central purpose of the federal government $[\ldots]$ to protect ordinary Americans not from abuse by state governments, or from general economic collapse, but from acts of criminal violence by other Americans" (Simon, 2004, p. 344). Not everyone was content with allowing the government this authority, especially in the post-Vietnam years when the United States lost its first major conflict and shattered the national self-image (Gibson, 1994). This view of the federal government as protector collided with the historical knowledge from the old West that had "politically infantilized" individual citizens and subjugated white citizens under the rule of territorial administrators (Obert, 2018, p. 201). Landmark civil right cases such as Brown v. Board of Education eroded the community's rights to decide who had access to public spaces and instead required equality of access. Religious leaders, such as Jerry Falwell, began invoking the language of individual rights to protect religous freedom (Bellah et al., 2007; Harding, 2000). Use of the individual rights narrative created a shared space for religious activists and political activists (MacLean, 2018) to be joined by gun rights activists. Gun rights advocates, then, argue that guns are the most straightforward way for individuals to protect themselves from the failures of government and their fellow man.

\section{Religion, politics, and nationalism}

Religion and politics have been intertwined throughout American history (Bellah et al., 2007; Gorski, 2017b). Bellah and coauthors' (1996, 2007) Habits of the Heart stands as the seminal piece arguing that American civic life involves an element of religious obligation, a stance that extends back through de Tocqueville's Democracy in America. Two significant criticisms of Bellah's work are relevant to the current argument that religious nationalism has changed discourse surrounding the Second Amendment. The first is that Bellah's work focused predominantly on Protestant voices in American history (Yamane, 2007). This criticism, however, enhances the current argument given its focus on the relationship between the rise of the New Christian Right and the NRA's rhetoric.

A second significant criticism of Bellah is that he did not clearly differentiate between the civic religious tradition and religious nationalism (Gorski, 2017b). Gorski corrected this oversight by clearly defining religious nationalism as the fusion of "religion and politics, to make citizenship in the one the mark of citizenship in the other, to purge all those who lack the mark and to expand the borders of the kingdom as much as possible, by violent means if necessary" (2017b, p. 17). In the context of religious nationalism, the Second Amendment serves as a means to protect the right to engage in violence (Gorski and TürkmenDervişoğlu, 2013; Obert, 2018). More recently developed measures of Christian nationalism have shown that it is a significant predictor of negative attitudes toward gun control (Whitehead et al., 2018).

The rise of religious nationalism serves as a counterweight to secular nationalism, which "contends that the authority of a nation is based on the secular idea of a social compact between equals rather than on ethnic ties or sacred mandates" (Juergensmeyer, 2006, p. 358). Religious nationalism can be traced back to the founding of the nation (Craven, 2017; Juster, 2018), but the current merging of religion and politics arose from the turbulence of the 1960s, coming into full political force with Moral Majority founded by Jerry Falwell in 1979 (Wuthnow, 1990). Although the New Christian Right as a social movement was an influential force in American politics in the 1980s, the Moral Majority as an organization did not survive the 1980s. Nevertheless, the political decedents of the New Christian Right that emerged from it remain a powerful force in politics to date (Bowman, 2018; Gorski, 2017a; Woodberry and Smith, 1998), despite declining religiosity reported across all religious groups in America (Chaves, 2011; Hadaway et al., 1993).

\section{The political rise of the new Christian right and the NRA}

The rise of the New Christian Right in the 1980s provides the backdrop for the present study. The NRA rose to exceptional political power under Harlan Carter's leadership, joining the New Christian Right in capitalizing on the conservative backlash against the liberal gains of the 1960s (Melzer, 2012). Following Watergate, the 1970s were racked with significant ethics investigations at the highest levels of government, seeding concerns in conservative communities about a nation in moral decline led by an untrustworthy government (Wuthnow, 1990). Moral decline is at the center of the nationalist narrative (Gorski, 2017b) and both the NRA and the New Christian Right see America's problems as evidence of moral decline (Whitehead et al., 2018). The New Christian Right in the 1980s was something never before seen in the field of religion and politics: a group that was "morally outraged, socially engaged and routinely politically active" (Harding, 2000, p. 81). The New Christian Right similarly mobilized voters on issues surrounding morality. As Harding (2000) wrote, "morality and politics were being discussed in the same breath" (p. 202). The New Christian Right focused on absolute obedience to God's laws as the solution to the moral decay in America. According to this view, obedience to the word of God would stay God's hand in passing judgment on the nation (Harding, 2000; Wuthnow, 1990). The NRA mirrored this focus by casting the Second Amendment as a God-given right whose infringement would bring disaster to the nation (Hodges, 2015). It has been widely argued that Reagan would have lost the 1980 election if not for the concerted effort of the Moral Majority (Harding, 2000; Wuthnow, 1990), although the actual influence of this group remains contested (Woodberry and Smith, 1998).

The political turn toward Second Amendment absolutism was enabled by the NRA's ability to link "threats to gun rights and broad social and structural changes and cultural representations linked to gender and race relations...if people perceive that their rights, status, and identity are threatened, they will be motivated to act" (Melzer, 2012, p. 67). Indeed, the NRA has been incredibly effective in building on the Moral Majority's efforts in the culture wars (Harding, 2000; Woodberry and Smith, 1998; Wuthnow, 1990) by grafting gun rights onto larger cultural issues. Although the actual risk of adopting gun control legislation was at its highest in the 1960s following high-profile assassinations and rising violence (Waldman, 2015; Winkler, 2013), substantive gun control legislation at the national level was not passed until the Clinton administration in 1993/1994 (Dunbar-Ortiz, 2018). The subsequent association of Democrats with gun control and Republicans with gun rights helped speed the sorting of America into "red" and "blue." Further, over the last 40 years, political affiliation has emerged as one of the most significant predictors of religious affiliation (Chaves, 2011). This political and religious sorting enabled the NRA to use religious rhetoric in order to link the Second Amendment to Christian conceptions of what it means to be a real American (Bonikowski and DiMaggio, 2016). 


\section{The links between religion, nationalism, and guns}

Gun ownership is not explained solely by religious or political culture (Stroud, 2016; Yamane, 2017b) even though it is strongly associated with Protestantism, in a complex relationship that may be impossible to disentangle (Yamane, 2017a). Recent research suggests that gun ownership is negatively associated with religiosity (Mencken and Froese, 2017) and provides alternative ways for men to feel more valuable to their family and community. Rather, for some, gun ownership offers a sense of "moral purpose to white males who have lost, or fear losing, their economic footing" (Mencken and Froese, 2017, p. 22). In this way, the Second Amendment provides a sense of identity that is both religious and patriotic without being explicitly tied to any one organization or denomination. Guns offer a source of identity comparable to a sense of self previously rooted in religious identity (Carlson, 2015; Yamane, 2017a; Yamane et al., 2018). This identity as gun owner serving as a valued member of community is not new: it is related to an older form of civic obligation, particularly prevalent in the South in the form of slave patrols and militia membership, that "linked private effort [with] public order" (Obert, 2018, p. 148).

Following the Civil War, the military served an important role in enforcing national boundaries through the use of the conquest narrative: both physical boundaries through the use of force in establishing the nation in the American West, and symbolic ones through enforcing, however briefly, the political participation of freedmen in the South during Reconstruction (Obert, 2018). The "basic formula for religious nationalism in American history has been apocalyptic politics plus the conquest narrative" (Gorski, 2017b, p. 19). The conquest narrative focuses on the conquering of land for the Israelites and "legitimates political violence, particularly violent forms of nation building" (Gorski, 2017b, p. 21). The conquest narrative provides both a religious and a nationalist justification for the central importance of the Second Amendment by arguing that the it preserves the right of the individual to engage in violence to defend "true Americans" from evil of a tyrannical government or other threats to security.

Religious nationalism, then, finds fertile ground in "white respondents who have undergone or fear economic distress tend to derive self-esteem and moral rectitude from their weapons" (Mencken and Froese, 2017, p. 2). This same population "threatened by rapid cultural and economic changes" may be more susceptible to "nationalist political appeals" (Bonikowski, 2016, p. 19.7). Education becoming increasingly associated with radical secularism (Gorski, 2017b) has influenced the idea that conservative national identities are "explicitly delegitimized by the educational system" (Bonikowski, 2016, p. 19.7). Thus, the resurgence of religious nationalism at a time when white Christian Americans felt (accurately or not) deep institutional insecurity about their status in America is unsurprising ( $\mathrm{Am}$ et al., n.d.; Figlio, 2018; Hedges, 2008; Whitehead et al., 2018).

Conservative Protestants tend to be much more literal in interpreting the Bible, arguing for a plain reading of the text (Harding, 2000; Wuthnow, 1990). This approach can be clearly seen with regard to the NRA's emphasis on the plain reading of the Second Amendment's language "shall not be infringed" and the emergence of Second Amendment absolutism (Hodges, 2015). On the face of it, the structure of beliefs surrounding the Second Amendment maps onto several well-developed measures of Protestantism: (1) authority in the Bible and (2) the belief in the sinful nature of humanity. Protestantism is also significantly more individualistic than other Christian traditions (Weber, 2001; Woodberry and Smith, 1998). The trust in inerrancy of the Bible is a generally accepted measure of religiosity, particularly among Evangelical Protestants (Chaves, 2011). The absolute faith in the Scripture is not tempered by education or reason. Viewing the Second Amendment as a "God-given right" that "shall not be infringed" echoes in many ways the Biblical injunction not to alter the text in any way lest the person doing the altering find a sure pathway to Hell.

America has always been exceptional in the belief that the Constitution serves as a covenant with God (Dunbar-Ortiz, 2018). Whereas the Bible serves as the sacred text for Christians, the religious nationalist draws on the civic religious canon in which the "gospels are the Declaration of Independence and the U.S. Constitution" (Gorski, 2017b, p. 31). The 10 original amendments to the Constitution serve as the new Ten Commandments "handed down by God" (Melzer, 2012, p. 14), and here the role of biblical narrative in the NRA's transformation of the Second Amendment plays a pivotal role.

\section{Data and methods}

To measure the NRA's use of religious language and how it has changed over time, I conducted a discourse analysis of the NRA's longest-running and most far-reaching publication, the American Rifleman. By investigating the cultural meaning of religious language embedded in this publication, I aim to measure "the typical interpretation of some type of object or event evoked" by the text (Strauss, 2012; Strauss and Quinn, 1997). By reading the American Rifleman through a religious lens, I follow Geertz's insight that "meanings are socially established" (Geertz, 1973; Strauss and Quinn, 1997, p. 15). These shared meanings can and should be evaluated in broader cultural context of the American political and culture wars of the last 40 years. Critically, however, shared meanings cannot establish causality regarding the actual beliefs of individual NRA members. Instead, I investigate how the meaning surrounding the Second Amendment has been shaped by cultural elites.

Discourse can be studied without making claims about the beliefs of individuals (Strauss, 2012; Strauss and Quinn, 1997). Although significant potential criticisms surround discourse's ability to illuminate beliefs and values (Swidler, 2003; DiMaggio, 2014), evidence suggests that discourse can illuminate "patterns and structures" of social life (Wuthnow, 2011, p. 6). Through framing selection, discourse is able to enhance communication and emotional transmission of meaning (Benford and Snow, 2000). The similarity between social movements and religious movements (Hannigan, 1991) suggests that applying discourse analysis to religious texts can illuminate "social practice - patterned by the social institutions in which it is learned and... practiced... [and] internalized so that these rules often do not require conscious deliberation and yet observable in the structure and content of the discourse itself" (Wuthnow, 2011, p. 7).

The data for this research come from the corpus of the American Rifleman, the official magazine of the NRA that's been consistently published in its current form since the early 1920 s (O'Neill, 2007). An examination of the American Rifleman presents an opportunity to study the current emergence of religious nationalism in America, primarily because it is targeted toward broad NRA membership, rather than at core Second Amendment supporters like other NRA magazines (Melzer, 2012). As the longest-running NRA publication, the American Rifleman is representative of how the organization has communicated to its broadest base of readers and provides an ability to measure change over time. The American Rifleman has been in continuous circulation since 1923 under its current name (O’Neill, 2007), and its circulation represents one of the top 50 magazine distributions in the country (Waldman, 2015), even in today's increasingly digital environment. The NRA states that more than 2 million subscribers currently receive the American Rifleman every month (Keefe, 2018). The American Rifleman publishes 12 issues per 
year and has several long-running repeating columns, such as "The Armed Citizen" (begun in the 1920s), "Standing Guard" (begun after Wayne LaPierre assumed the role of Executive Vice President in 1991), and "Dope Bag" (begun in 1977).

The American Rifleman includes transcripts of major speeches given at the annual conventions each year, as well as presidential addresses focusing on key issues. The year 1977 marks the formal demarcation between the more moderate, old guard of the NRA and hardliners who pushed them aside to gain control of the NRA during what is known as the Revolt at Cincinnati (Waldman, 2015; Winkler, 2013). The new guard, led by Harlan Carter, focused on Second Amendment absolutism (Hodges, 2015; Melzer, 2012). This new focus on "shall not be infringed" reflected a long-term vision of Second Amendment absolutism for the NRA. While the debate about the nature of the Second Amendment and the NRA's role as an advocacy organization predates the 1970s, I argue that the religious nationalist transformation of the Second Amendment coincides with the rise of the New Christian Right. Reflecting the timing of the NRA's deliberate shift into political influence, this research focuses on a lexical shift from 1975 to the present, beginning two years prior to the 1977 Revolt at Cincinnati. In addition, 1975 marks the founding of the NRA's Institute for Legislative Affairs, the nonprofit organization focused on electing Second Amendment-friendly congressional representatives (Bruce and Wilcox, 1998), as well as the official end of the war in Vietnam. I begin with 1975 to show that the transformation of discourse toward more religious language was not employed as frequently prior to the 1977 takeover in Cincinnati or the 1979 rise of the Moral Majority. This approach allows an exploration of how the NRA's discourse evolved from political language to religious nationalist framings. I am not suggesting that such discourse did not exist prior to 1977, however, only that it shifts significantly after 1977.

My sample includes every issue from January 1975 to December 2018. Digital editions beginning with January 2008 were downloaded from a digital archive. Physical editions were accessed through library archives or purchased from collectors through online vendors, such as eBay. Physical editions were scanned using Adobe Scan to create digital editions and were then optimized for text analysis using publicly available optical character recognition software, ABBYY FineReader. Where optical character recognition was unclear, the actual text was read and selected passages were transcribed. Issues average approximately 100 pages in length, with election-year issues being about $20 \%$ larger.

I use a mixed-methods approach to analyze the corpus of the American Rifleman from 1975 to 2018. First, I familiarized myself with much of the language that appears in the text, as well as in other NRA-centric media, such as video ads, focusing on how various NRA spokespeople currently discussed Second Amendment. I also searched for language used in fundamentalist Christian discourse paying attention to the narrative style of moralizing sermons (Harding, 2000; Luckmann, 2003).

Building on Morning (2008), I then coded results for direct discussions of the Second Amendment tied to religious discourse. These often involve discussions of "God" and "God-given" rights. Indirect discussions focus on links between religion and nation (e.g., "God bless" or "thank God"). Finally, I coded for implicit discussion related to the religious nationalist discussion of the Second Amendment. Use of religious language, such as references to mountains and sacrifice, and other metaphors create frames that may resonate more with right-leaning audiences (Lakoff, 2004).

I focus on direct and indirect discussions using textual analysis that focuses on the increasing use of religious language for two reasons. First, it is impossible to know what the readers of the
American Rifleman believe; however it is possible measure the text they are reading and make assumptions about the role of the NRA in influencing the links between religion and nationalism. This approach offers a contextualized assessment of religious language (Engler and Gardiner, 2017) surrounding the Second Amendment as opposed to measuring the inherently sacred properties of the Second Amendment itself. Second, direct and indirect discussions are "particularly suited to marking trends over time because they are relatively objective indicators" (Morning, 2008, p. S115) of the changing use of religious language surrounding the Second Amendment within the specified corpus.

\section{Reading the American Rifleman as religious text}

With the success of the Civil Rights movement in the Jim Crow South, groups such as the NRA and the New Christian Right began to study how rights were invoked and how laws were used to challenge or protect these rights in the courts (Waldman, 2015). The New Christian Right was explicitly focused on expanding civil rights for Christian Americans, modeling their actions on the success of the Civil Rights movement (Harding, 2000; Wuthnow, 1990). After seeing the Civil Rights movement's legal and legislative success, Falwell stated that he "hoped Christians would have the kind of backbone to stand up for their rights that Civil Rights people had" (Harding, 2000, p. 22). Human, and by extension civil, rights became formally recognized by the international community through the United Nations Universal Declaration of Human Rights in 1948 (Joas, 2013; Moyn, 2010).

The NRA, however, has not linked rights to the UN Declaration but rather draws their conception of rights directly from God. The NRA's tying of human rights back to God is not merely a clever marketing trick. Joas (2013) traced two streams regarding the emergence of human rights: one that extends back through the Enlightenment and pure reason, and another that traces back through Christian and Jewish religious traditions.

Figure 1 shows the changing frequency of the word "God" in the American Rifleman from 1975 to 2018. Religious nationalism did not completely appear on the political scene in the late 1970s, but references to God appeared more frequently following the 1977 NRA takeover by hardliners. These references were not entirely absent in the years prior to Harlan Carter's leadership. Direct references to God increased in the mid-1990s, appearing after a reshuffling of the NRA board of directors and removal of some of the hardline "extremists" (Knox, 2009, p. 366) by LaPierre and his supporters. The NRA leadership frequently thanked God, who is often viewed as a shepherd leading the flock through dark times, a reference to Psalm 23. As Melzer noted, inperson references to God are never "tongue in cheek" (Melzer, 2012 , p. 13) but are reflections of sincere belief. "God bless" is almost always used in reference to NRA leadership, America, or political leaders.

Figure 2 shows the increasing use of "God-given" from 1975 to 2018, as well as the changing associations of God-given with rights, to bear arms and self-defense. Usage of "God-given" in the 1980s was tied to shooting ability and raw talent, a usage that reappeared in the discussion of Charlton Heston's talent in 2008. The sole 1990 instance is tied to stewardship of the land, a usage that did not reappear in subsequent issues. In 1994, there is an explicit focus on trading a "God-given right to a government granted privilege" (NRA Staff, 1994, p. 52), emphasizing the elevated status of something granted by God as opposed to protected by government.

On the face of it, this phrase views rights not granted by government or humans but instead as descending straight from 


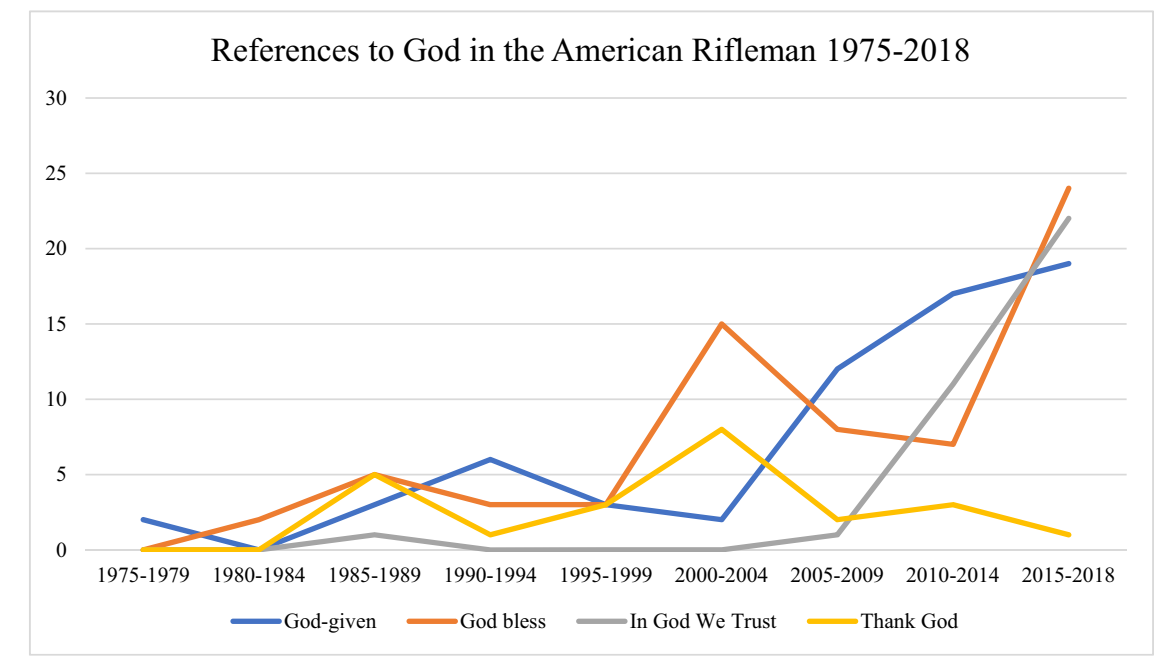

Fig. 1 References to God in the American Rifleman from 1975 to 2018. This figure is covered by the Creative Commons Attribution 4.0 International License. Reproduced with permission of Jessica Dawson; copyright (c) Jessica Dawson, all rights reserved

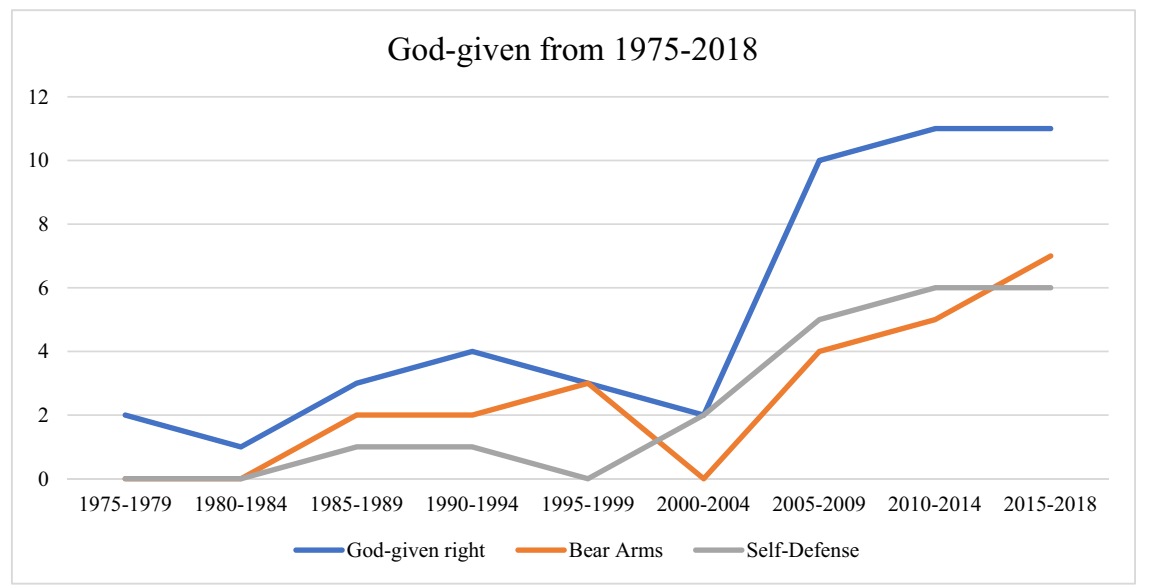

Fig. 2 Frequency of "God-given" in the American Rifleman from 1975 to 2018. This figure is covered by the Creative Commons Attribution 4.0 International License. Reproduced with permission of Jessica Dawson; copyright (c) Jessica Dawson, all rights reserved

the Creator. "God-given" appeared in the American Rifleman approximately 64 times since 1975 , but the frequency of its use was inconsistent over time. Harlan Carter appears to have been one of the first to use the term in the American Rifleman, two years after the takeover in Cincinnati by Second Amendment hardliners (Melzer, 2012).

Our NRA Members stand foremost in the struggle to protect and preserve all our God-given, constitutional and long-accepted rights. We stand foremost among those who see and recognize clearly the unfailing mix and combination of those rights with the right of the people to keep and bear arms. (Carter, 1979, p. 55)

Figure 2 shows that the use of the phrase "God-given right" dramatically increased beginning in 2008, coinciding with the rise the concealed carry movement (Carlson, 2015; Stroud, 2016; Yamane et al., 2018). It is not merely the frequency of the phrase that demonstrates the lexical shift but also its usage explicitly with reference to bearing arms or self-defense.

"The American people... will never surrender their right to protect themselves, defend their families and defend their freedom here in the United States of America," [LaPierre] proclaimed. "The National Rifle Association will always defend that God-given birthright from every enemy out there, both foreign and domestic!" (NRA Staff, 2009, p. 84)

The subsequent frequency of "God-given right" after April 2008 could be deliberately linked to President Obama's ascension to the White House, a Democrat president who was deeply unpopular in certain parts of the country and was suspected of not being a legitimately elected official (Carlson, 2015; Stroud, 2016). In addition, for some, a black man in the Oval Office was seen as a deep moral violation and signaled that the government no longer worked for the perceived average (white) Americans (Dunbar-Ortiz, 2018). By invoking religious nationalism, the NRA moved more mainstream, appealing to a broader themes in American nationalism (Bonikowski and DiMaggio, 2016) of voters beyond the single-issue gun rights voters (Melzer, 2012).

The NRA has explicitly invoked the Second Amendment as a "God-given right" deliberately to remove it from the bounds of legal authority of the state. The "Standing Guard" column offers an example of the rhetoric depicting the Second Amendment as beyond the reach of the government.

...men and women who care about their safety will never let themselves be shamed, ridiculed or accused of being "unreasonable" for defending their God-given right to defend life and limb. We've proven it over and over again, 
and we'll do it again on Election Day. So let this be a declaration to America's leaders: You have no right, no reason and no authority to deny us the protection that the Second Amendment alone guarantees. (LaPierre, November 2014, emphasis added)

It evokes a religious nationalism that cannot be restrained by the authority of the very government it claims to support and seeks to restrain the government's ability to force individuals to adhere to policies they disagree with (Bowman, 2018; MacLean, 2018). This deliberate denial of the government's authority draws on both a literal, originalist reading of the Constitution and the idea that the Constitution stands as a covenant between God and the American people.

\section{Heston's use of the moralizing sermon}

The figure of Moses and the Exodus narrative is prominent in American religious history. The Puritans saw themselves as fulfilling their role as new Israelites, setting out for the promised land. At least twice, NRA leadership has been likened to Moses, building on the prevalence of the Exodus narrative in American religious discourse (Gorski, 2017b). NRA President Charlton Heston was instrumental in the movement of the NRA to the mainstream. Heston's faith was always prominent and was reflected in many of the roles for which he is remembered, specifically Moses in the Ten Commandments. Heston used his iconic imagery and powerful oratory skills to invoke the link between the Second Amendment and God and to solidify it for the faithful. By using spiritual language toward that end, Heston successfully linked his image in the American psyche as Moses to the new American Ten Commandments (Melzer, 2012). "God gave us Moses [referring to Heston]. Heston...is the reason the NRA has moved into the mainstream" (Melzer, 2012, p. 13).

Heston's portrayal of Moses was significant in several deeply American ways. The Exodus story figures prominently throughout different periods in American history (Dunbar-Ortiz, 2018). For example, the Pilgrims saw themselves as part of the Exodus story, fleeing a repressive England for their faith. Martin Luther King Jr. frequently invoked the Exodus narrative in his marches for freedom in the Jim Crow South. Heston's portrayal of Moses built on a deeply held American belief of persecution by an unjust government (Gorski 2017a, 2017b). His charisma, reflected in his oratory skills and his statesmanlike appearance, his association with his archetypical portrayal of Moses, and his well-known personal faith enabled him to lead the NRA membership through the storm following the massacre at Columbine High School in 1999 (Cullen, 2010).

Charismatic leaders possess the greatest potential to change society (Parsons, 1993) and to shape conceptions of the sacred. As part of the sacralization process, the charismatic leader identifies something new and central to the belief system. As Lewis and Hammer (2011) wrote, "in Weberian terms, emergent movements typically gather around charismatic figures" (p. 4). Charlton Heston filled this role for the NRA and used his charisma to declare a crusade to save the Second Amendment. His rhetoric, however, was not merely powerful speech but deliberately invoked religious language and metaphors. In the September 1997 issue of the American Rifleman, Charlton Heston declared "My Crusade to Save the Second Amendment" (Heston, 1997), echoing evangelical leader Billy Graham's "Crusades for Christ" a generation earlier (Wuthnow, 1990).

Heston used rhetoric recognized by Christian Americans, including a reference to joining him in the arena-a metaphor drawing on the biblical story from the book of Daniel about believers being fed to lions for refusing to reject their beliefs (Harding, 2000).
As the 21st Century dawns, I won't stand by and watch the Second Amendment die. Wayne LaPierre asked me to come back to the arena. It is my time-and it is your time-to serve. (Heston, 1997, p. 12)

Heston invoked religious language in suggesting that the Second Amendment and the Bill of Rights were handed down to America by God, building on deeply American traditions (Bellah et al., 2007; Heston, 2000a).

You cannot evoke the spirit of this sacred text without remembering that the script bears deep, deep scars. Friendships, families, even the greatest of nations have been torn apart over the principles these words so carefully spell out. Young and old, rich and poor, men and women of all races and creeds and religions all over the earth have stood tall-or sunk lifeless to the ground-embracing the weight of these simple truths. (Heston, 1997, p. 32)

His reference to the "spirit of this sacred text" speaks to the Pentecostal element of the "new Christian chimera" that was "part fundamentalist, part Pentecostal, part charismatic, part evangelical" (Harding, 2000, p. 80). In stating that there is "something inherently special about our nation" (Heston, 1997, p. 32 ), he implicitly referenced the belief that the Constitution is a new covenant between God and the American people (Dunbar, 1998; Gorski, 2017b).

In his "Crusade" article, Heston assumed the role of witness. "Witnessing, like evangelistic preaching, is intended to create a spiritual crisis by calling to the fore one's desperate and lost condition, which one many have been totally unaware of' (Harding, 2000, p. 38). He directly invoked a sense of conviction, which "engenders a sense [that] something must be done" (Harding, 2000, p. 38).

I am back because I see a nation of children, a couple of entire generations, that have been brainwashed into believing the Second Amendment is criminal in origin, rather than framed within the Constitution (Heston, 1997, p. 32).

So now we must move. Understand up front that there is no room in the middle. You must either stand aside or step forward with us in this partnership to save the Second Amendment (Heston, 1997, p. 34)

His call to gun owners to fight for the Second Amendment echoes the structure of moralizing religious sermons (Luckmann, 2003), drawing on prophetic biblical metaphors deeply embedded in American culture (Dunbar-Ortiz, 2018; Gorski, 2017b; Melzer, 2012). Moralizing sermons tend to have three main parts: "the description of the present evil, a prophecy of doom, followed by a call for repentance" (Luckmann, 2003, p. 197). In Heston's depictions, the "present evil" is the threat to the Second Amendment, which "is America's First Freedom, the one right that protects all others...The right to keep and bear arms is the one right that allows 'rights' to exist at all"' (Heston, 1997, p. 32). By invoking memories of how "Americans waded up those bloodred beaches at Okinawa and fought in the muddy fields of Vietnam for more than mere words" (Heston, 1997, p. 32), Heston implied that without the willingness of men with guns, the Second Amendment would become nothing more than "polite platitudes of public discourse" (Heston, 1997, p. 32).

The prophecy of doom follows. Americans will be "herded, humbled and ruled" and will sacrifice the rest of their rights without the "right to keep and bear arms [as] the one right that allows 'rights' to exist at all” (Heston, 1997, p. 32). Heston stated, "it would be a sin against everything this nation stands for to let 
the cornerstone of our Constitution erode away out of simple neglect" (Heston, 1997, p. 34), explicitly tying religious failing of sin to the political realm of the political compromise.

The call for repentance references a frequent biblical metaphor of the mountain, as well as a regathering of the faithful (Harding, 2000): "I'm urging our NRA membership to reunite and rededicate itself to a monumental struggle-the tallest mountain we will ever climb" (Heston, 1997, p. 33). Not only does his reference to a mountain invoke his own role as Moses and the receiving of the Ten Commandments, but it also draws on the civil religious rhetoric of Martin Luther King Jr. and his wellknown Mountaintop speech. Mountains figure prominently in both the Old and New Testaments as sacred places where individuals such as Moses and Jesus spoke with God (Harding, 2000). In addition, Heston's call to repentance explicitly implored NRA members to act decisively: "there is no room in the middle. You must either stand aside or step forward with us." $\mathrm{He}$ argued that failure to act would mean watching "an entire generation of American youth drift off course into disaster, while the freedoms they would have cherished...erode away" (Heston, 1997, p. 34). He invoked the implicit language of rights by asking members "will you march with me?" implicitly linking the Second Amendment to the Civil Rights marches (Gorski, 2017b; Harding, 2000).

Heston's speech at the NRA annual meeting following the Columbine massacre followed a similar prophetic structure by opening with a statement of the present misery. The prophecy of doom continues, predicting the fracturing of the country if its enemies are successful in pitting Americans against one another.

I see our country teetering on the edge of an abyss. At its bottom brews the simmering bile of deep, dark hatred. Hatred that's dividing our country politically, racially, economically, geographically, in every way.

This harvest of hatred is then sold as news, as entertainment, as government policy. Such hateful, divisive forces are leading us to one awful end: America's own form of Balkanization. A weakened country of rabid factions, each less free, and united only by hatred of one another. (Heston, 1999, 13 emphasis added)

I am asking all of us, on both sides, to take one step back from the edge of that cliff. Then another step and another, however many it takes to get back to that place where we're all Americans again...different, imperfect, diverse, but one nation...indivisible. This cycle of tragedy-driven hatred must stop. Because so much more connects us than divides us. And because tragedy has been and will always be with us. Somewhere right now, evil people are scheming evil things. All of us will do every meaningful thing we can to prevent it. But each horrible act can't become an axe for opportunists to cleave the very Bill of Rights that binds us.

... [Y]ou'd better give them that eternal bodyguard called the Second Amendment. The individual right to bear arms is freedom's insurance policy, not just for your children but for infinite generations to come...

That is its singular sacred beauty and why we preserve it so fiercely. It is not a right without rational restriction and it's not for everyone. Only the law-abiding majority of society deserves the Second Amendment. Abuse it once and lose it forever. That's the law. But remarkably, the NRA is far more eager to prosecute gun abusers than are those who oppose gun ownership altogether... as if the tool could be more evil than the evildoer (Heston, 1999, 14, emphasis added)

Heston served as a witness for NRA members, linking faith in God to action needed to defend the Second Amendment. His use of moralizing sermons focused on mobilizing the NRA membership for "averting the threat" and avoiding continuing in the "present misery...understood as sin" (Luckmann, 2003, p. 391). Moralizing sermons "served the construction and maintenance of moral order for many centuries in Western society" and are a "time-honored form of direct moralizing" (Luckmann, 2003, p. 401). Heston merged the political with the religious, referring to the individual right to bear arms as something sacred-that is, set apart from the profane everyday life and infused with its own referential power (Durkheim, 1912). Critically, Heston acknowledges that the Second Amendment is not a "right without restriction" signaling that for him, at least, the second Amendment was not absolute but rather reserved only for the righteous -in his words the "law abiding majority" (Heston, 1999, p. 14). In his call for a crusade, Heston did not, however, directly identify the source of the threat, leaving the evil implied, and therefore more frightening, to serve as a source of motivation for action (O’Neill, 2007).

\section{Evil among us}

The NRA's use of "terror-filled narrative" provides a central theme linking the defeat of evil to the actions taken by NRA members (O’Neill, 2007, p. 459). Evil occupies an interesting place in American religion and society, despite the secular turn. As the sacred slipped free of churches (Demerath, 2003), so too did the understanding of evil and the rituals used to control it. Sociological explorations of evil have been limited, treating evil frequently as a social problem to be solved rather than as a consequence of cultural understandings (Alexander, 2001). After the Columbine massacre and the events of $9 / 11$, the media played a strong role in reshaping Americans' understanding of evil in everyday life. The NRA was not alone in defining Columbine using a "discourse of fear" (Altheide, 2009, p. 1365). School shootings and terrorism made evil more real for everyday Americans and also less controllable. Evil is not objective, however; rather, the perception of evil comes from an "interpretation of events and their presumed causes" (Turk, 2004, p. 271). That said, all major world religions "permit, and may even require, violence in the defense of the faith" and suggest that "[c]reatures of cosmic evil... are to be annihilated" (Turk, 2004, p. 277).

Evil, especially in these uncertain times of significant social change (Bonikowski, 2016) marks the world as uncertain-a place where "attackers challenge the trust in the assumed order" (Altheide, 2009, p. 1361). Being confronted with evil forces people to face the stark reality of their own vulnerability (Neiman, 2015). Religion and ritual have served every human society's need to control uncertainty and evil (Durkheim, 1912; Russell, 1987). Religion, however, also competes with the state as a means of organizing and controlling violence (Friedland, 2001), and America's own violent founding extends from the merging of religion and political will (Dunbar, 1998; Juster, 2018; Obert, 2018). The NRA's gradual embrace of religious nationalism suggests a worldview in which its preservation of the right to enact violence "declares the absence of state guarantee," fundamentally rejecting the notion that the state provides any control over violence (Friedland, 2001, p. 129). The NRA advocated protection of the individual means to engage in violence as a means of "restoring the moral order" (Turk, 2004, p. 277).

Evil serves as a mechanism to understand direct discussions of religious language in the American Rifleman. References to evil over time in the American Rifleman illustrates the merging of 


\section{Types of Evil in the American Rifleman from 1975-2018}

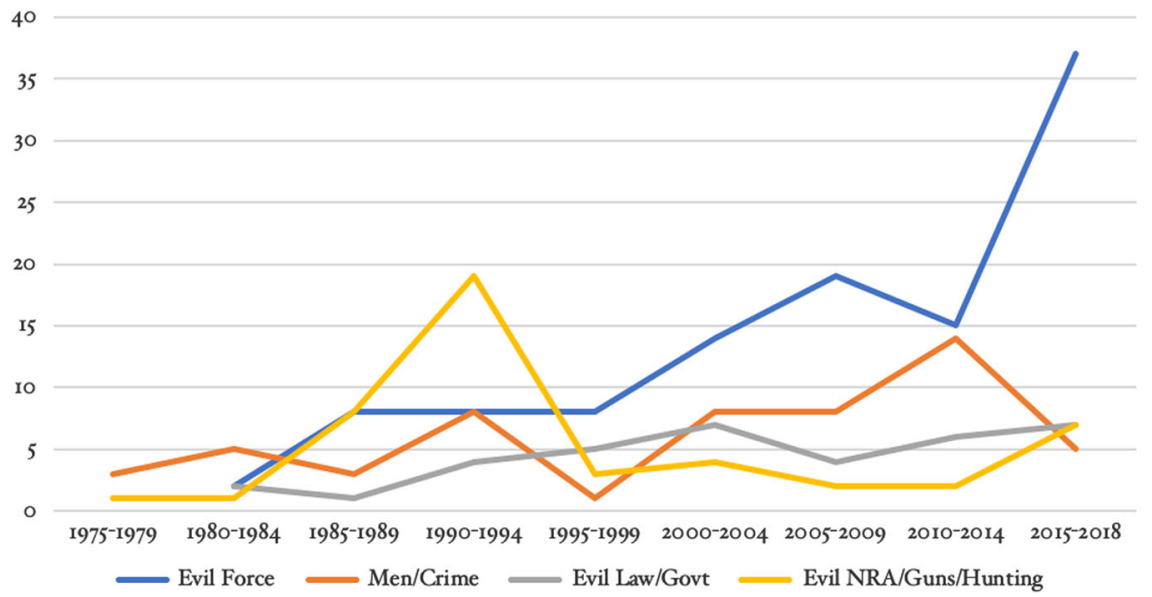

Fig. 3 References to Evil in the American Rifleman from 1975 to 2018. This figure is covered by the Creative Commons Attribution 4.0 International License. Reproduced with permission of Jessica Dawson; copyright (c) Jessica Dawson, all rights reserved

American civic religion with the New Christian Right's rhetoric. I coded for main references to evil: (1) evil as an unseen or disembodied force, (2) evil used to describe the NRA, guns or hunting by anti-gun advocates, (3) evil men or criminals, and (4) evil laws or government.

Figure 3 shows that references to evil appear more frequently after the takeover of hardline Second Amendment absolutists in 1977 but increased significantly following the Columbine massacre and the events of $9 / 11$ in the early 2000s. In addition, what was referred to as evil also changed over time, shifting from describing guns as evil in an effort to caricature gun rights opponents' arguments to referring to a more disembodied evil. One of the earliest uses of describing laws as evil comes from Neal Knox in 1979 where he described laws that would deprive individuals of their rights as evil. The implication is that anyone who would deprive a law-abiding citizen of this fundamental human right is not merely expressing an opposing political view but is also promoting an evil agenda meant to undermine American sovereignty (Barker and Bearce, 2013).

The past decade has brought us one fundamental truth. Evil man with evil intent will inflict all manner of abuse on a segment of the public and the color of an evil law and a 1968 Gun Control Act is an evil law. (Knox, 1979).

This early use of "evil," however, laid the foundation for later such uses to describe criminals after LaPierre was elected as the Executive Vice President in 1991. No longer were criminals other citizens subject to the rule of law; they were creatures to be violently removed. The legal institution could no longer be trusted to uphold the moral order, so it was left to the armed, law-abiding citizen to cleanse the streets of evil.

If my actions have spared only one family from the distress and trauma that this habitual criminal has caused hundreds of others, then I have served my civic duty and taken one evil creature off of our streets, something that our impotent criminal justice system had failed to do, despite some thirty odd arrests, plea bargains and suspended sentences. (LaPierre, 2008, 12 emphasis added)

The notion of engaging in one's civic duty to remove an evil monster represents another merging of civic and religious obligations. This right to self-defense draws on the deeply embedded American right to life, which is encoded in the Declaration of Independence but goes even further:
This right to self-defense was not invented by the American founders but has roots that are older than civilization itself. It is inscribed on every human heart. It is a sacred responsibility-a choice that most mainstream Americans understand. (LaPierre, 2008, p. 12)

References to evil in the American Rifleman exploded at the same time as the concealed carry movement around 2008, likely due to both Obama's election and the massive economic recession (Stroud, 2016). Critically, the merging of the religion based reference to "evil" with the language of civic duty demonstrates the how the framing around the Second Amendment has changed over time.

The NRA emerged as combative and uncompromising following the massacre by refusing to move its annual conference from Denver (Cullen, 2010).

The majesty of the Second Amendment that our founders so divinely captured and crafted into your birthright, guarantees that no government desperate, no renegade faction of armed forces, no roving gangs of criminals, no breakdown of law and order, no massive anarchy, no force of evil or crime or oppression from within or from without can ever rob you of the liberties that define your Americanism. (Heston, 1999, p. 14)

This approach marked a change in the NRA's response to school shootings over the next two decades, which was marked by a merging a defiant, "more guns" stance and Second Amendment absolutism (Hodges, 2015) with a religious obligation to "restore the moral order" (Turk, 2004, p. 277). This rhetorical notion of evil mirrors Falwell's tendency to paint political opponents as agents of Satan, focusing not on political victories that would enable compromise but on total dehumanization of America's enemies (Clarke, 2016; Oliver and Wood, 2014; Goertzel, 1994; Hodges, 2015).

Columbine marked a deepening of the shift in references to evil, further linking the absence of the rule of law to the subsequent failure of the government. Defining the mass shooters as evil builds on born-again Christians' belief that the Devil is literal and real (Harding, 2000) but also requires violent defensive actions rather than a reliance on the law to restrain the lawless. This justification would be used successfully again and again following mass shootings over the two decades following Columbine: laws would not stop someone bent on harming the 
innocent (Demons at our Door, 2015; LaPierre, 2012). The description of the Columbine shooters as "twisted terrorists" and "a stone-hearted death squad" invokes imagery of irrational actors-monsters hiding in "plain" sight as "kids" demonstrates the need to always be on guard.

The school terrorists were America's children-just plain "kids" - and that somehow the guns they used made them do it. But the Littleton, Colorado murderers Eric Harris and Dylan Klebold were not America's children. They were a stone hearted giggling death squad who openly planned the murders for a year-who even made school sponsored video acting out their horrific crimes. Nobody in authority paid attention....Long before they celebrated Hitler's birthday by killing innocent schoolmates, these twisted terrorists could've been intercepted and stopped if only if someone in authority had paid attention. (LaPierre, 1997, p. 10, emphasis added)

The Second Amendment, then, offers power to the "common man" to protect himself and his family from extraordinary evil, and this "sacred stuff" comes directly from the divine (Heston, 2000b). Associating shootings such as those at Columbine, Aurora, or Sandy Hook with depraved monsters who cannot be stopped by the rule of law (Demons at our Door, 2015), the NRA argues that the only logical step is to take up arms to protect home and kin and that relinquishing guns in the face of evil means surrendering to it. Ads run by the NRA support this rhetoric, providing a dark and ominous worldview that requires "us" to protect ourselves from "them." One NRA video describes a dangerous world where freedoms are under attack not by others with whom we disagree but by "demons among us" (Demons at our Door, 2015).

You and I didn't choose to be targets in the age of terror. But innocents like us will continue to be slaughtered in concert halls, sports stadiums, restaurants and airplanes. No amount of bloodshed will ever satisfy the demons among us. These cowards dream of inflicting more damage, more suffering, more terror. No target is too intimate or too sacred for these monsters. They will come to where we worship, to where we educate, to where we live. But when evil knocks on our doors, Americans have a power no other people on the planet share-the full-throated right to defend our families and ourselves with our Second Amendment. Let fate decide if mercy is offered to the demons at our door. I'm the National Rifle Association of America and I'm freedom's safest place. (Demons at Our Door, 2015, emphasis added)

Critically, these so-called demons are not law-abiding citizens. They are criminals, gangsters, and thugs-monsters who cannot be constrained by the law. Guns serve as a mechanism not only to define the individual as a hero (Carlson, 2015; O'Neill, 2007; Stroud, 2016) but also to define reality around the idea that the individual is inherently dangerous and untrustworthy, building on Protestant beliefs about the sinful nature of the mankind and the fallen nature of the world (Harding, 2000). The Second Amendment offers protection from these manifestations of the evil. A critical part of this tyrannical overreach involves depriving the individual citizen of the right to self-defense. In this definition of the situation (Heise, 1979; MacKinnon and Heise, 2010), there are clearly evil people who should not have access to guns but do, making it an abdication of an individual's moral duty not to be armed and prepared to defend against it. By this logic, it is completely rational to want to take action to defend against the dangerous monsters, who, by their very nature, generally conceal their intentions until they strike (Collins, 2014).

\section{The merging of the Second Amendment with religious nationalism}

Christian nationalism has a long history in the United States (Bowman, 2018; Gorski, 2017b; Juster, 2018), and the NRA has successfully used Christian nationalist rhetoric to turn "politics into religious obligation" (Friedland, 2001, p. 126). The conflict between the state and religion is centrally the problem of authority. Despite being ostensibly a political lobbying group, the NRA has yoked its model of authority to the divine, rejecting the idea that the secular government can claim authority over what God has granted. In doing so, the NRA has elevated the defense of the Second Amendment to the role of religious obligation in the political sphere. As the United States turned toward secular governance, Christian nationalism was reborn, and the NRA embraced these rhetorical devices to further its own messaging.

The NRA adopted two critical frames that helped align the Second Amendment with the New Christian Right's religious nationalism: distrust in the government and rugged individualism (Obert, 2018; Yamane, 2017b; Yamane et al., 2018). First, distrust in government has deep roots in American history. A significant and influential stream in Protestant thought involves the "strongly anti-political and anti-civic side. The state and larger society are unnecessary because the saved take care of themselves" (Bellah et al., 2007, p. 16). Second, rugged individualism involves paranoia and fear of the state inherited from the founding of the nation. Jeffersonian and Madisonian republicanism "viewed with hostility not only cities, but also taxation and virtually any function for the state. A paranoid fear of the state is not something new but can be seen from the earliest days of the republic" (Bellah et al., 2007, p. 16). Both of these frames built on the idea of the rights of individuals to be free from the government's influence in their daily lives (Bowman, 2018; MacLean, 2018).

Under the leadership of hardliners such as Harlan Carter and Neal Knox, the NRA began to transition to a more absolutist stance regarding the Second Amendment in the late 1970s. With the rising political influence of the New Christian Right, the NRA leadership began to use more religiously coded language to elevate the Second Amendment above the restrictions of a secular government, building on New Christian Right rhetoric about the role of God in the U.S. Constitution. The New Christian Right built on deeply American views that the Constitution was divinely inspired and held: "institutional truths about the proper form of government" and could not be altered (Gorski, 2017b, p. 181).

The NRA's use of religious nationalism also served as means of retaining "membership in the political community" (Friedland, 2001, p. 130) at a time when Christian feelings of persecution by the state continued to grow (Bowman, 2018; Harding, 2000; Hedges, 2008; Woodberry and Smith, 1998; Wuthnow, 1990). Significant Supreme Court decisions that limited the rights of Christians to pray in public schools (Bowman, 2018) along with the New Christian Right's fear of moral decline prompted them to push back against the power of the state by deliberately seeking to control it (Harding, 2000; Wuthnow, 1990). In Weberian terms, the New Christian Right embraced a legal rational authority, no longer content to wait for a charismatic authority to turn America back to the Lord, (Weber, 1946). Conversely, the NRA sought to elevate the Second Amendment through the use of charismatic authority while also seeking to carve protected sacred space for it in the legal sphere.

Harlon Carter was the first NRA leader to be "seen as Moses, George Washington and John Wayne" (Melzer, 2012, p. 38) after the 1977 Revolt at Cincinnati, which was the dawn of the NRA's hardline stance toward the Second Amendment. Carter directed the political turn of the NRA toward a hardline stance (Knox, 2009). LaPierre built the NRA as an institution anchored in nationalism, referred to as the "rock of the NRA" (Melzer, 2012, 
p. 13), a not unsubtle reference to Peter, one of Jesus disciples and founder of the Christian church. Following Carter, however, the spirit of Moses was more explicitly embodied-both literally and symbolically-in Charlton Heston, who arrived to shepherd the NRA faithful across the religious and temporal boundaries of the new millennium and merged the obligation with civic duty (Melzer, 2012).

\section{Conclusion}

This study demonstrates the NRA's use of religious nationalist discourse to elevate the Second Amendment beyond the reach of the state. Drawing on the New Christian Right's belief in moral decay, distrust of the government, and belief in evil, along with the "paranoid style of American politics" (Hodges, 2015; Hofstadter, 1970), the NRA used shared metaphors to link the Second Amendment to religious nationalism, moving clearly toward Second Amendment absolutism. The linking of religious language with civic duty builds on a long history of religious nationalism in American history (Bellah, 1992; Gorski, 2017b; Yamane, 1998). The NRA may have invoked religious framing because their membership would likely be more receptive to the frames of religiously motivated, politically active people of faith (Lakoff, 2004). More research is needed to explain whether this language resonated (McDonald et al., 2017) with individual members of the NRA and, more broadly, beyond the bounds of the NRA membership to the broader gun owning community.

Critically, this research does not argue that all NRA members are religious nationalists nor that all religious nationalists are NRA members or even gun owners. There is significant overlap in those populations, however (Hovey et al., 2017; Yamane, 2017b; Yamane et al., 2018), and future research should investigate where those boundaries are permeable or impenetrable. In addition, this paper focuses on the discursive overlap between the NRA and the New Christian Right, but more research is needed to establish how this overlap occurred and where the boundaries lie. Although recent research has shown a negative association between religiosity and gun ownership, this study shows how the NRA has borrowed from religious language to create "alternative symbols and identities" that potentially create a hybrid identity that is more religious nationalist than purely religious or civic minded (Mencken and Froese, 2017, p. 21).

This paper does not make a causal connection between NRA rhetoric and member beliefs. Future research should investigate to understand the ways in which gun ownership and religious nationalism overlap with or diverge from traditional Protestant beliefs and practices (Whitehead et al., 2018). Future research should also investigate how individual gun owners engage with the Second Amendment both as a focal point of religious nationalism and as a civic and religious identity (Mencken and Froese, 2017). Additional research is needed to investigate the ways in which religious nationalism is present or missing in broader gun culture (Burbick, 2006; Yamane, 2017b) as well at the ways this language is adopted or discarded by diverse groups, such as women and racial or religious minorities.

This paper offers a potential mechanism for explaining how the NRA molded "Gun Crusader's deep commitment to gun rights... [as well as] to the NRA's current and future ability to remain a potent political force" (Melzer, 2012, p. 254). I demonstrate that the NRA cultivated commitment to the Second Amendment as a deep-seated piece of religious nationalism that offers "a cultural solidarity and commitment [rooted in] identity, morality, and patriotism [of] gun ownership" (Mencken and Froese, 2017, p. 22 ). Over the last 40 years, the NRA has deliberately pivoted to protecting the Second Amendment, not as something merely important but as something sacred to be defended at all costs from the profane hands of the government. The NRA has done this by deliberately using religious imagery, language, and icons such as Charlton Heston, that map onto the largely Protestant religious beliefs and religious nationalism tracing back to the founding of the nation. The present analysis suggests that the Second Amendment may offer a sense of meaning-making that allows men to feel like protectors of their families and their homes against an evil that cannot be contained by the rule of law. In this sense, the arming of the average law-abiding citizen is a completely rational response to the increasingly random threat that is deeply felt in parts of American society. These threats do not need to be real in order to have real consequences (Merton, 1995, 1968).

\section{Data availability}

Some of the digital editions of the American Rifleman from 2009 to the present were downloaded from nextbooks website: http:// www.nxtbook.com/nxtbooks/nra/ar_XXXXYY. The main url is provided but there is no central archive linking to each issue that the author is aware of. To find specific issues, replace the XXXX with the year and the YY with the month. An example would be the August 2009 issue at the attached link: http://www.nxtbook. com/nxtbooks/nra/ar_200908/. Older editions were purchased and manually digitized and cannot be made public without written permission from the NRA. The rest of the corpus was manually digitized and due to copyright protections, it cannot be shared without written consent from the NRA. Print copies of the American Rifleman were retrieved and manually scanned using Adobe Scan from the library collections, as well as purchased online from individual merchants.

Received: 27 October 2018 Accepted: 4 June 2019

Published online: 02 July 2019

\section{References}

Alexander J (2001) Toward a sociology of evil: getting beyond modernist common sense about the alternative "to the good". In: Lara M (ed) Rethinking evil: contemporary perspectives. University of California Press. Berkeley and Los Angeles, California

Altheide DL (2009) The Columbine shootings and the discourse of fear. Am Behav Sci 52:1354-1370. https://doi.org/10.1177/0002764209332552

Am MA (n.d.) Why the Christian right's persecution fantasies are so dangerous. Alternet.

http://www.salon.com/2014/02/07/

why_the_christian_rights_persecution_fantasies_are_so_dangerous_partner/ Accessed 7 Feb 2014

Barker DC, Bearce DH (2013) End-times theology, the shadow of the future, and public resistance to addressing global climate change. Polit Res Q 66:267-279. https://doi.org/10.1177/1065912912442243

Bellah RN (1992) The broken covenant: American civil religion in time of trial, 1st edn. University of Chicago Press, Chicago

Bellah RN, Madsen R, Sullivan WM, Swidler A, Tipton SM (2007) Habits of the heart: individualism and commitment in American Life, 1st edn. With a New Preface edn. University of California Press. Berkeley and Los Angeles, California

Benford RD, Snow DA (2000) Framing processes and social movements: an overview and assessment. Annu Rev Sociol 26:611-639

Bonikowski B (2016) Nationalism in settled times. Annu Rev Sociol 42:427-449. https://doi.org/10.1146/annurev-soc-081715-074412

Bonikowski B, DiMaggio P (2016) Varieties of American popular nationalism. Am Sociol Rev 81:(5)949-980. 0003122416663683

Bowman M (2018) ChrisTian: the Politics of A Word in America. Harvard University Press, Cambridge

Bruce JM, Wilcox C (1998) The changing politics of gun control. Rowman and Littlefield, Maryland

Burbick J (2006) Gun show nation: gun culture and American democracy, 1st edn. The New Press, New York 
Carlson J (2015) Citizen-protectors: the everyday politics of guns in an age of decline, 1 edn. Oxford University Press, Oxford; New York

Carter H (1979) What is the NRA. Am Riflem 127:54-55

Charles PJ (2018) Armed in America: A history of gun rights from colonial militias to concealed carry. Prometheus Books, Amherst, New York

Chaves M (2011) American religion: contemporary trends, 1 edn. Oxford University Press, Princeton

Clarke S (2016) Conspiracy theories and conspiracy theorizing. Philosophy of the Social Sciences 32:131-150

Collins R (2014) Micro-sociology of mass rampage killings. Rev Synthèse 135:405-420. https://doi.org/10.1007/s11873-014-0250-2

Craven AG (2017) Sacred violence in early America by Susan Juster. Magic Ritual Witch 12:256-259. https://doi.org/10.1353/mrw.2017.0026

Cullen D (2010) Columbine. Twelve. New York

Demerath NJ (2003) Secularization Extended: From Religious "Myth" to Cultural Commonplace, in: Fenn RK (ed), The Blackwell Companion to Sociology of Religion. Blackwell Publishers, Oxford, p 211-228

Demons at our Door (2015) National Rifle Association

DiMaggio P (2014) Comment on Jerolmack and Khan. "Talk Is Cheap": ethnography and the attitudinal fallacy. Soc Methods Res. https://doi.org/10.1177/ 0049124114526371

Dunbar RI (1998) The social brain hypothesis. brain 9:10

Dunbar-Ortiz R (2018) Loaded: a disarming history of the Second Amendment. City Lights Publishers, San Francisco

Dunseith BT (n.d.) "Good Guys": the ethical lives of gun owners 138

Durkheim E (1912) The elementary forms of the religious life. Free, New York

Engler S, Gardiner MQ (2017) Semantics and the sacred. Religion 47:616-640. https://doi.org/10.1080/0048721X.2017.1362784

Figlio K (2018) Fundamentalism and the delusional creation of an enemy. In: Krüger S, Figlio K, Richards B (eds) Fomenting political violence. Springer International Publishing, Cham, p 149-166. https://doi.org/10.1007/978-3319-97505-4_8

Friedland R (2001) Religious nationalism and the problem of collective representation. Annu Rev Sociol 27:125-152. https://doi.org/10.1146/annurev.soc.27.1.125

Geertz C (1973) The Interpretation of cultures. Basic Books, New York

Gibson JW (1994) Warrior dreams: violence and manhood in post-Vietnam America, Reprint edn. Hill and Wang Pub, New York

Goertzel T (1994) Belief in conspiracy theories. Political Psychology 15:731

Gorski PS (2017a) Why evangelicals voted for Trump: a critical cultural sociology. Am J Cult Sociol. https://doi.org/10.1057/s41290-017-0043-9

Gorski PS (2017b) American covenant: a history of civil religion from the puritans to the present. Princeton University Press, Princeton

Gorski PS, Türkmen-Dervişoğlu G (2013) Religion, nationalism, and violence: an integrated approach. Annu Rev Sociol 39:193-210. https://doi.org/10.1146/ annurev-soc-071312-145641

Hadaway CK, Marler PL, Chaves M, (1993) What the polls don't show: a closer look at US church attendance. Am Sociol Rev 58:741-752

Halbrook SP (2013) That every man be armed: the evolution of a constitutional right, revised and updated edition, Revised and Updated edition. University of New Mexico Press, Albuquerque

Halbrook SP (2008) The founders' Second Amendment: origins of the right to bear arms, 1st edn. Ivan R. Dee/Independent Institute, Chicago

Hannigan JA (1991) Social movement theory and the sociology of religion: toward a new synthesis. Sociol Anal 52:311. https://doi.org/10.2307/3710849

Harding SF (2000) The Book of Jerry Falwell: fundamentalist language and politics. Princeton University Press, Princeton

Hedges C (2008) American fascists: the christian right and the war on America, Reprint edition. Free Press, New York

Heise DR (1979) Understanding events: affect and the construction of social action. Cambridge University Press, Cambridge, New York

Heston C (2000a) Journal of the House of Representatives, State of Arizona, 2000, Forty-Fourth Legislature, Second Regular Session, Fourth to Seventh Special Sessions. Ariz Mem. https://azmemory.azlibrary.gov/digital/collection/ hrjournal/id/106. Accessed 25 May 2018

Heston C (2000b) My Cold DEAD Hands-NRA speech https://www.liveleak.com/ view? $\mathrm{i}=\mathrm{dfa} \_1356207495$. Accessed 29 May 2018

Heston C (1999) The President's Column. Am Riflem. 147:12-13

Heston C (1997) My crusade to save the Second Amendment. Am Riflem 145:30-34

Hodges A (2015) The paranoid style in politics: Ideological underpinnings of the discourse of Second Amendment absolutism. J Lang Aggress Confl 3:87-106. https://doi.org/10.1075/jlac.3.1.04hod

Hofstadter R (1970) America as a Gun Culture. Am Herit 21

Horwitz J, Anderson C (2009) Guns, Democracy, and the Insurrectionist Idea. University of Michigan Press. Ann Arbor, Michigan

Hovey C, Fisher L, Boaz R, Crews GA, Crews GA, Gentle-Genitty C, Kim J, Kumar B, Renguette C, Ryan M, Stolick M, Yamane D (2017) Understanding America's gun culture. Lexington Books, Lanham
Joas H (2013) The sacredness of the person: a new genealogy of human rights. Georgetown University Press, Washington, D.C

Juergensmeyer M (2006) Nationalism and religion. In: Delanty G, Kumar K (eds) The SAGE Handbook of Nations and Nationalism. SAGE Publications Ltd, London; Thousand Oaks, California

Juster S (2018) Sacred violence in early America, Reprint edn. University of Pennsylvania Press. Philadelphia

Keefe M (2018) The Keefe report. Am Riflem 166:8

Knox N (2009) The Gun Rights War. Macfarlan Press. Phoenix, Arizona.

Knox N (1979) Knox Declares War on 1968 Gun Control Act. Am Riflem 147:7

Lakoff G (2004) Don't think of an elephant!: know your values and frame the debate-the essential guide for progressives, 1st edn. Chelsea Green Publishing, White River Junction, $\mathrm{Vt}$

Lamy P (1992) Millennialism in the mass media: the case of "Soldier of Fortune" magazine. J Sci Study Relig 31:408. https://doi.org/10.2307/1386853

LaPierre W (2012) Remarks from the NRA press conference on Sandy Hook school shooting, delivered on Dec. 21, 2012 (Transcript). Washington Post. https:// www.washingtonpost.com/politics/remarks-from-the-nra-press-conferenceon-sandy-hook-school-shooting-delivered-on-dec-21-2012-transcript/2012/ 12/21/bd1841fe-4b88-11e2-a6a6-aabac85e8036_story.html. Accessed 3 Aug 2018

LaPierre W (2008) Standing Guard: Barack Obama’s Slippery Oratory. Am Riflem 156:10

LaPierre W (1997) Standing Guard. Am Riflem 146:10

LaPierre W (2009) Standing Guard: The right to self defense trumps the elites lies. Am Riflem 157:12

Lewis JR, Hammer O (eds) (2011) The invention of sacred tradition, Reissue edn Cambridge University Press, Cambridge

Luckmann T (2003) Moralizing Sermons, then and now. In:Fenn RK (ed) The Blackwell Companion to Sociology of Religion. Wiley-Blackwell, Malden

MacKinnon NJ, Heise DR (2010) Self, identity, and social institutions. Palgrave Macmillan, New York

MacLean N (2018) Democracy in chains: the deep history of the radical right's stealth plan for America, Reprint edn. Penguin Books

McDonald T, Bail C, Tavory I (2017) A theory of resonance. Soc Theory 35:1-14 Melzer S (2012) Gun crusaders: the NRA's culture war. NYU Press, New York

Mencken FC, Froese P (2017) Gun culture in action. Soc Probl. https://doi.org/ 10.1093/socpro/spx040

Merton RK (1995) The Thomas theorem and the Matthew effect. Soc Forces 74:379. https://doi.org/10.2307/2580486

Merton RK (1968) Social theory and social structure, in: social theory and social structure. Free Press, Glencoe, p 39-117. 175-213

Morning A (2008) Reconstructing race in science and society: biology textbooks, 1952-2002. Am J Sociol 114:S106-S137. https://doi.org/10.1086/592206

Moyn S (2010) The last Utopia: human rights in history. Belknap Press, Cambridge

Neiman S (2015) Evil in modern thought: an alternative history of philosophy, Reissue edn. Princeton University Press, Princeton

NRA Staff (2009) Defend Freedom Now. Am Riflem 157:80-85

NRA Staff (1994) Am Riflem 142:52

Obert J (2018) The six-shooter state: public and private violence in American politics. Cambridge University Press, Cambridge

Oliver JE, Wood T (2014) Conspiracy Theories and the Paranoid Style(s) of Mass Opinion. Am J Pol Sci 58:952-966

O'Neill KL (2007) Armed citizens and the stories they tell: the national rifle association's achievement of terror and masculinity. Men Masc 9:457-475. https://doi.org/10.1177/1097184X05281390

Parsons T (1993) Introduction to Weber's sociology of religion. In: Fischoff E (ed) The sociology of religion. Beacon Press, Boston, (Trans)

Russell JB (1987) The devil: devil: perceptions of evil from antiquity to primitive Christianity, Reprint edn. Cornell University Press, Ithaca

Simon J (2004) Gun rights and the constitutional significance of violent crime William Mary Bill Rights J 12:23

Strauss C (2012) Making sense of public opinion: American discourses about immigration and social programs. Cambridge University Press, Cambridge

Strauss C, Quinn N (1997) American Anthropological Association, Meeting (eds) A cognitive theory of cultural meaning. Cambridge University Press, Cambridge, New York

Stroud A (2016) Good guys with guns: the appeal and consequences of concealed carry, Reprint edn. The University of North Carolina Press, Chapel Hill

Swidler A (2003) Talk of love: how culture matters. The University Of Chicago Press, Chicago

Turk AT (2004) Sociology of terrorism. Annu Rev Sociol 30:271-286. https://doi. org/10.1146/annurev.soc.30.012703.110510

Waldman M (2015) The Second Amendment: a biography, Reprint edn. Simon \& Schuster, New York

Weber M (2001) The Protestant ethic and the spirit of capitalism. Routledge, London; New York 
Weber M (1946) The Types of Authority and Imperative Co-ordination, in: Parsons, T., Henderson, A.M. (Trans.), The Theory of Social and Economic Organization. Free Press, New York

Whitehead AL, Schnabel L, Perry S (2018) Gun control in the crosshairs: christian nationalism and opposition to stricter gun laws. Socius 4:1-13. https://doi. org/10.31235/osf.io/3ag7k

Winkler A (2013) Gunfight: the battle over the right to bear arms in America, 1 edn. W. W. Norton and Company, New York

Woodberry RD, Smith CS (1998) Fundamentalism et al: Conservative protestants in America. Annu Rev Sociol 24: 25-56

Wuthnow R (2011) Taking talk seriously: religious discourse as social practice. J Sci Study Relig 50:1-21

Wuthnow R (1990) The restructuring of American religion, Reprint edn. Princeton University Press, Princeton

Yamane D (2017a) Awash in a sea of faith and firearms: rediscovering the connection between religion and gun ownership in America. J Sci Study Relig. 00:1-15

Yamane D (2017b) The sociology of U.S. gun culture. Sociol Compass 11:e12497. https://doi.org/10.1111/soc4.12497

Yamane D (2007) Introduction: habits of the heart at 20. Sociol Relig 68:179-187. https://doi.org/10.1093/socrel/68.2.179

Yamane D (1998) Bellah, Robert N. In: Swatos Jr W (ed) Encyclopedia of Religion and Society. AltaMira Press, Maryland

Yamane D, Ivory SL, Yamane P (2018) The rise of self-defense in gun advertising: the American Rifleman, 1918-2017. GunStudies, Routledge

\section{Acknowledgements}

I would like to thank David Yamane for encouragement and support in figuring out the central argument of this paper, Lauren Valentino for multiple reviews and argument

clarification, and Simon Brauer for his insights into the religious rhetoric literature. This paper would still be in draft without their work. In addition, Riley Nolan, Niquelle Cassador, and Ben Mammel were indispensable with helping digitize the records for this research. I have to thank Remi Hajjar and Beth Wexler for comments that helped shape the early direction of this paper.

\section{Additional information}

Competing interests: The author declares no competing interests.

Reprints and permission information is available online at http://www.nature.com/ reprints

Publisher's note: Springer Nature remains neutral with regard to jurisdictional claims in published maps and institutional affiliations.

(c) (i) Open Access This article is licensed under a Creative Commons Attribution 4.0 International License, which permits use, sharing, adaptation, distribution and reproduction in any medium or format, as long as you give appropriate credit to the original author(s) and the source, provide a link to the Creative Commons license, and indicate if changes were made. The images or other third party material in this article are included in the article's Creative Commons license, unless indicated otherwise in a credit line to the material. If material is not included in the article's Creative Commons license and your intended use is not permitted by statutory regulation or exceeds the permitted use, you will need to obtain permission directly from the copyright holder. To view a copy of this license, visit http://creativecommons.org/ licenses/by/4.0/.

(c) The Author(s) 2019 